January 2018

\title{
Gender Demographics and Perception in Librarianship
}

Patricia Mars

Catholic University, 44mars@cua.edu

Follow this and additional works at: https://scholarworks.sjsu.edu/ischoolsrj

Part of the Archival Science Commons, Cataloging and Metadata Commons, Collection Development and Management Commons, Information Literacy Commons, Scholarly Communication Commons, and the Scholarly Publishing Commons

\section{Acknowledgements}

This article was originally composed as an assignment for Prof. Amanda's Wilson class, Information Professionals in Society, at the Catholic University of America. The author would like to thank Prof. Wilson for her guidance throughout the course.

\section{Recommended Citation}

Mars, P. (2018). Gender Demographics and Perception in Librarianship. School of Information Student Research Journal, 7(2). https://doi.org/10.31979/2575-2499.070203 Retrieved from https://scholarworks.sjsu.edu/ischoolsrj/vol7/iss2/3

This article is brought to you by the open access Journals at SJSU ScholarWorks. It has been accepted for inclusion in School of Information Student Research Journal by an authorized administrator of SJSU ScholarWorks. For more information, please contact scholarworks@sjsu.edu. 


\title{
Gender Demographics and Perception in Librarianship
}

\begin{abstract}
This article is an examination of the history of gender demographics in the field of librarianship. The historic development and subsequent "feminization" of librarianship continues to influence the gender wage gap and the disproportionate leadership bias in the field today. This article examines the stereotyping of librarians and the cyclical effect of genderizing the profession. Consideration of current trends and data in librarian demographics demonstrates a consistent decrease in gender diversity, accompanied by a troubling lack of women leaders and executives. Additionally, this article explores options for combating the gender perceptions that negatively impact women in library and information science fields, including management and negotiation training in graduate programs, increased emphasis on technological skills, and professional organization advocacy.
\end{abstract}

\section{Keywords}

gender, stereotypes, librarianship

\section{Acknowledgements}

This article was originally composed as an assignment for Prof. Amanda's Wilson class, Information Professionals in Society, at the Catholic University of America. The author would like to thank Prof. Wilson for her guidance throughout the course.

\section{About Author}

Patricia Mars is a student in the Master of Science in Library and Information Science program at the Catholic University of America. 


\section{Introduction}

The gender pay gap, despite much attention and discussion, remains a pervasive social justice concern in the American workforce. According to the White House Council of Economic Advisors (2015), women, on average, earn 78 cents to every dollar that a man earns (para. 2). The field of librarianship is not immune to this problematic wage inequality. However, the situation of librarianship is particularly unique, because women make up the majority of the profession. Despite this female majority in the library workforce, there remains both a wage inequality between genders, and an unequal proportion of men in leadership roles. Beyond the pay gap and the leadership bias in the field, librarians are often plagued by stereotypes, many related to gender, that perpetuate these issues and lead to false perceptions and "feminization" of the library profession. This exploratory essay examines the root of these issues through a study of the historic gender demographics of librarians, through a consideration of gender stereotypes in the field, and finally, through an analysis of current trends and data in libraries. Further, this paper explores options to combat the negative gender perceptions that plague the profession.

\section{Historical Overview of Gender in the Library Profession}

Rubin (2016) gives a brief overview of the history of gender perceptions in U.S. libraries, beginning with the first female clerk hired by the Boston Public Library in 1852 (p. 286). From this lone female library employee in 1852, "by 1878 two-thirds of the library workforce was female, and by 1910 more than $75 \%$ of the library workers were women" (Rubin, 2016, p. 286). Women have continued to dominate the library profession to this day. Rubin (2016) does offer a few theories as to why women were so drawn to library work and why they have consistently made up the majority of the workforce. One of the initial reasons for the flux of women in 
librarianship stems from the social developments of the nineteenth century. Library systems were rapidly expanding, and this expansion called for additional workers. However, much like today, many libraries faced funding shortages and financial difficulties. In the 1800s, women were willing to work for a much lower salary than most male employees were, and in fact, "male library directors openly acknowledged the desirability of hiring talented women because they worked for half the pay" (Rubin, 2016, p. 287).

Libraries were certainly not the only places that took economic advantage of women, and Jane Simon (1994) writes "denied access to a living wage on the assumption that they were supported by men, women were thus forced into relations of dependence" (p. 258). While the workplace has changed since the 1800s, this inequality of wages remains from this earlier philosophy. These early assumptions regarding dependent relationships positioned women in an inferior relationship to men in the professional world of librarianship as well. Men were assumed to be the primary breadwinners. This assumption is a potential cause of the library leadership gender bias, as men were consistently given higher salaries and positions than their female counterparts. Simon (1994) goes on to explain that in the early days of women in the workforce, "women had the right to paid work only after men's need for such work was satisfied. They should not compete with men for work, especially if it was well paid and had prospects for career advancement" (p. 258).

Beyond the financial advantage of hiring female librarians in the nineteenth century, there were also sociological reasons for the rapid increase of women in the profession. Women in the workplace was a still a new phenomenon, and many believed that women ought to only work in professions that catered to "natural, feminine" skills, such as caregiving and homemaking. Rubin (2016) elaborates, "because libraries were seen as civilizing and nurturing, 
they were acceptable places for women to work" (p. 287). Additionally, the idea that libraries were centers for self-improvement and moral development meant that women were viewed as being especially suited to this "missionary work" (Rubin, 2016, p. 287). However, once again, this idea that libraries were pantheons of moral development and that women were delicate, passive guides in this quest, had far-reaching consequences: "women were perceived as more delicate and unable to tolerate the rigors of administration" (Rubin, 2016, p. 287). This perception, while perhaps unconsciously, has continued to influence the gender of library leadership positions to this day.

\section{Feminization: The Pay Gap and Leadership Bias}

While libraries did open a positive new frontier for women to work outside the home, this opportunity had negative effects as well, including the creation of stereotypes and unnecessary genderization of the profession. Librarianship is an example of a field that has been "feminized," much like nursing or social work. Debra Gold Hansen, Karen F. Gracy, and Sheri D. Irvin (1999) defined feminization as a process in which an increased number of women in the workforce lead to "depressed salaries, limited professional advancement, and [segregation of] women into low-status, nonadministrative positons" (p. 312). The rapid increase of female librarians meant that a feminine stereotype emerged in addition to these sexist limiting factors. Though as Hansen, Gracy, and Irvin (1999) also point out, the fact that the majority of librarians were women meant that women did influence the shape of an emerging profession, a unique opportunity, and one that women used to establish a perceived “'gender-linked value system' of altruism, advocacy, and intellectual uplift" (p. 312). These early influencers affected the development of many libraries' modern service-based missions. 
Many early female librarians were ambitious, and dedicated to the library mission and expansion. Unfortunately, their talents were often limited by the male library leaders and the continued gender discrimination in the field, and so women librarians were often considered “active partners," not “equal partners" (Hansen, Gracy, \& Irvin, 1999, p. 312). Men entering librarianship were often fast-tracked toward leadership roles, over equally qualified and successful woman employees. In some cases, "even the most successful woman professional could find herself removed from her administrative post or demoted to a less responsible position" (Hansen, Gracy, \& Irvin, 1999, p. 312). In the twenty-first century, there are fewer extreme cases of this outright gender discrimination. Yet, men continue to disproportionately represent library leaders, and the wage gap continues. Both issues are legacies of nineteenth century discrimination and social inequalities.

\section{Gender Stereotypes in Librarianship}

Feminization of the library field affected salaries and career mobility, but it also affected the reputation of librarians themselves. "Garrison (1972-1973) suggested that the feminization of public librarianship in the nineteenth century created an inferior image for the profession that it might not have had if it remained the domain of male scholars" (Rubin, 2016, p. 287). Librarianship was thus perceived as "women's work"; the image of the field no longer had the prestige it once did when men were the primary librarians. In her review of Roma M. Harris' Librarianship: The Erosion of a Woman's Profession, Ellen Crosby (1993) further explains, "the work is not seen to be professional simply because it is being done by women" (p. 147). As this perceived "masculine" scholarly prestige fell away, so did the number of men who became librarians, further contributing to the process of feminization and perpetuating the stereotype that 
library work was womanly. Women continued to enter the library field, while men were less inclined to do so.

This decreased professional prestige is particularly jarring because nineteenth century female librarians were dedicated, competent professionals. American women librarians in 1891 frequently needed to "write steadily six or seven hours a day, know half a dozen languages, be absolutely accurate in copying; understand the relation of all arts and sciences to each other and have an intimate acquaintance with geography, history, art, and literature. A successful librarian worked 8 to 10 hours a day...” (Simon, 1994, p. 259). Despite these rigorous librarian requirements of the nineteenth century, and the rigorous modern requirements of twenty-first century librarians (not the least of which is a Master's degree), the profession still does not merit the same respect as the fields that remained dominated by men.

Woman have pushed to break the glass ceiling throughout the twentieth and twenty-first centuries, and woman today have opportunities to pursue careers in many fields that were formerly reserved for men. Interestingly though, "men are less likely to enter female sex-typed occupations than women are to enter male-dominated jobs" (Hickey, 2006, para. 4). Because librarianship is viewed as feminine, men are less likely to join the field, which then continues to increase the female majority creating a cyclical stereotype about librarianship as a feminine profession. The reasoning behind why men may be less likely to join "feminine" careers than women are to join "masculine" careers is complex, and largely outside the scope of this paper. The psychology behind male and female career choices as a whole rests, among other things, with essentially arbitrarily assigned sexual characteristics and social pressures. The gender demographic in librarianship is related to this psychology, but can be considered independently 
because of its unique situation with the many pervasive stereotypes that are associated with libraries and librarians.

Rubin (2016) describes the stereotypical librarian; "they are spinsters, wear their hair in a bun, buy sensible shoes and glasses, look stern, act like policeman —authoritarian and controlling — and are quick to say 'shhussh' at the slightest disturbance" (p. 284). Not only is this stereotype of a woman, it is a particular kind of woman. This image of a shrewish, unpleasant woman is alienating both to library patrons, and to potential future librarians. This stereotype might cause men not to consider librarianship at all, as they might not feel as though they are the "type." Hickey's (2006) articles suggests that men in the library field "are 'doubly stigmatized' due to stereotypes of librarianship as women's work and a 'traditional negative image of librarians"” (para. 7).

Beyond this negative female image that is the stereotypical librarian, Rubin (2016) mentions that some male librarians also "feared being seen as ineffectual or effeminate" (p. 284). Hickey (2016) also points out an assumed association with male librarians and homosexuality (para. 7). This fear of appearing effeminate relates back to the larger psychological issues at play, and to the societal pressures that people feel. Many feel pressure to conform to certain traits that have been traditionally labeled feminine and masculine, and pursue careers that fit those labels.

This "double stigma," and effeminate stereotype, however, may be somewhat exaggerated. In fact, data in Hickey's (2016) research shows that "'the male librarian sees himself in a worse light than the general population actually pictures him', prompting [the conclusion] that male librarians 'are fighting an image that does not exist'" (para. 7). Men in the library field feel these stereotypes more acutely than people outside the field. Unfortunately, the 
fact that most people do not entertain a negative stereotype around male librarians is almost irrelevant considering that male librarians do perceive it and thus inadvertently perpetuate it. The stereotype lives on, and continues to discourage men from joining the profession. Heidi Blackburn (2015) succinctly describes this pattern, stating "men assume the stereotypes are valid, they avoid taking the jobs, and the profession continues to see fewer males entering the workforce, creating a self-fulfilling prophecy of low employment rates" (para. 1).

\section{Current Trends}

The historic development of library staffs and the subsequent stereotyping of librarians have influenced the demographic make-up of the modern library profession. Women remain the majority of librarians, and continue to face economic inequality in the field and underrepresentation in leadership roles. The American Library Association (ALA) provides data regarding these leadership roles and the respective salaries from 1999. In academic libraries, men occupied $43 \%$ of all library director roles, and in public libraries, men occupied 35\% of library director roles (ALA, 1999). This data appears confusing, because it seems to suggest that women actually do make up the majority of library directors. However, these percentages are somewhat misleading. In 1999, women made up 78\% of librarians (Hansen, Gracy, \& Irvin, 1999, p. 312). Thus, men made up $22 \%$ of librarians. In both academic libraries and public libraries, men held a disproportionate number of leadership roles compared to women in 1999. Additionally, male library directors made more than their female counterparts in both academic and public library settings. Particularly in the case of public libraries, men, on average, were making \$10, 834 more than women (ALA, 1999). 
In 2010, the ALA released another demographic analysis that proved these trends continued into the second decade of the twenty-first century. In 2010, 81\% of MLS students were women, and $82.8 \%$ of all working librarians were women (ALA, 2011, p. 2). The percentage of male librarians had dropped to $17.2 \%$ in 2010 , and yet men still accounted for $40 \%$ of academic library directors (ALA, 2011, p. 3). Unsurprisingly, the wage gap continues in the library field as well. In libraries, women's weekly earnings averaged just $81 \%$ of men's weekly earnings (ALA, 2011, p. 3). Perhaps even more troubling, "on average, women have more years of experience than men, but men's salaries are still higher in nearly all 10 experience cohorts" (ALA, 2011, p. 3). The gender wage gap is even more significant for women of color (Patten, 2016, para. 4).

\section{Conclusion}

The "feminization" of the library field, based on both the actual female majority and the unfortunate stereotypes, affected the salaries and career potential of women librarians. Feminization depresses wages and caps advancement. The process also has an unfortunate effect of limiting gender diversity in librarianship. There is no doubt that the American workforce still faces gender inequalities, and the library field is no exception. The library field is unique from other professions because it is associated with a history of deliberate financial moves and "feminization." Women came to dominate the library field in the nineteenth century, when library directors and other leaders realized the need for more library staff but had limited funds. Because women were just beginning to leave the home and join the workforce, they were willing to work for low pay. Hiring women was a good financial choice for the survival of libraries. This novel situation in which women dominated a profession allowed women to engage with 
library missions and influence the direction of future libraries. This unique opportunity continues to this day, and librarianship remains a field in which women are the driving workforce. However, social mores in the nineteenth century continued to limit female advancement in the workplace, as women were viewed as gentle caretakers, excellent in nurturing librarian roles, but unfit for management.

Women were not frequently given leadership roles or empowered within the system. Instead, librarianship developed the unpleasant stereotype of being"women's work," and additional stereotypes emerged as well, painting female librarians as dull, strict spinsters. The stereotype influenced the growth of an already female majority profession, and men still do not become librarians at nearly the same rate as women to this day.

The situation in modern libraries owes much to this historic development and stereotyping. Wage and leadership inequalities still exist, and women remain the majority of the workforce. The task of these libraries today is to begin eliminating wage injustice and the bias in leadership decisions. Additionally, libraries must work to reverse the feminization of the field to banish stereotypes, allow for upward mobility, and increase gender diversity of librarians.

So how can librarians and information professionals begin to reverse the negative effects of feminization without sacrificing the strengths of the pioneering feminine influence on the field? How can librarians foster increased gender diversity in the profession and cultivate a positive image for professional librarianship? The process begins in the graduate degree programs. Masters of Library and Information Science programs need to incorporate courses in leadership and business management. Library students should be trained to recognize wage inequality and leadership bias in the field, and more importantly, should be trained to advocate for themselves and for their colleagues. Many MBA programs have focus areas for women's 
leadership programs, and this model could be adapted to suit the needs of a female majority graduate student population at risk of leadership bias in their future work environments.

The Tepper School of Business at Carnegie Mellon University serves as an exemplar model of a program that markets extensively to female applicants, and focuses on the improved workplace outcomes for women who participate in leadership training. The school also hosts other executive education opportunities, such as the Carnegie Mellon Leadership and Negotiation Academy for Women, which trains the participants in "strategic visioning, leadership branding, expanding networks of influence, and navigating barriers" (Carnegie Mellon Leadership and Negotiation Academy for Women, 2017). This specific training when applied to library science students could give graduates the skills needed to combat pay inequality and leadership bias. The Simmons College MBA program provides another example of a business program that prepares students to tackle gender inequality in the workforce. The faculty in the School of Management is over 70\% female, with professors and scholars who have practical experience as leaders and executives (Why Gender Diversity Matters in BusinessMBA@Simmons, 2017). Future generations of librarians could benefit from training under accomplished female faculty who focus on gender equity in the workplace and on the reversal of the negative consequences of feminization.

Additionally, library degree programs need to advertise the technical skills, data management, and information science aspects of the graduate curriculum. The emphasis on science and scholarship increases the professional image of librarians, which has a two-fold advantage in increasing gender diversity and increasing pay. Computer science degree programs are male-dominated and yield high paying jobs (Saujani \& Sweet, 2016, para. 3). While librarians may not have the in-depth training of a true computer science degree, library graduate 
work does include coursework in digital content creation and management, in web design, and in information architecture and data science. Awareness of this technical training can positively affect the professional reputation of librarians and create conditions to successfully justify increased pay. These technological skills and focus areas can also help to abate the stereotypes surrounding librarianship, which suggest that library work exists exclusively in a perceived "feminine" sphere of subdued caretaking and nurturing. Emphasis on scientific skill and scholarship could combat existing negative stereotypes and consequently attract a more genderdiverse student population. Library graduate programs are already teaching these skills. The mission for these schools now is to advertise these features and demonstrate the varied abilities of their graduates.

Outside of degree programs, the existing female majority of professional librarians has the power to advocate for progressive changes. Professional organizations like the American Library Association can lend organizational structure for women's movements to fight for equal pay for equal work. Advocacy groups and committees can unite women despite geographic differences, and these groups can work to implement protective policies like gender-neutral standard pay scales based on experience level. Professional organization committees would also provide a resource for women who feel they have experienced unfair treatment in the workplace. The ALA currently does have a Committee on the Status of Women in Librarianship (COSWL) dedicated to the concerns of women in the field (ALA, 2017). Involvement in this committee and others at the local level can empower women to speak out against wage inequality and leadership bias, and provide support when combatting gender-based injustice.

Women librarians today have unprecedented opportunities and role models; for the first time in history the Librarian of Congress is a woman. Dr. Carla Hayden is the first woman, the 
first person of color, and the first professional librarian in over sixty years to hold the title (ALA, 2016, para. 1). Her ascent offers hope that the landscape of librarianship is changing, and that women can overcome the hurdles of feminization and leadership bias. However, Dr. Hayden is the exception that proves the rule. After over a century of a female majority in the library field, it is only now, in the second decade of the twenty-first century, that a woman serves in the highest leadership position in the American library realm. Librarians must pursue concrete strategies to improve the situation for ambitious women, and invest in research on the effects of negative gender perceptions. Such research has the potential to motivate internal action and mobilize the majority to create a more equitable environment for librarians of any gender. 


\section{References}

American Library Association (ALA). (1999). Library directors: gender and salary. Retrieved from http://www.ala.org/research/librarystaffstats/diversity/libdirectors

American Library Association (ALA). (2011). Library workers: facts and figures. Retrieved from http://ala-apa.org/files/2012/03/Library-Workers-2011.pdf

American Library Association (ALA). (2016). Dr. Carla Hayden to serve as the next Librarian of Congress. Retrieved from http://www.ala.org/news/press-releases/2016/07/dr-carlahayden-serve-next-librarian-congress

American Library Association (ALA). (2017). Committee on the status of women in librarianship (COSWL). Retrieved from http://www.ala.org/groups/committees/ala/ala$\operatorname{coswl}$

Blackburn, H. (2015). Gender stereotypes male librarians face today. Library Worklife. Retrieved from http://ala-apa.org/newsletter/2015/09/08/gender-stereotypes-malelibrarians-face-today/

Carnegie Mellon Leadership and Negotiation Academy for Women. (2017). Retrieved from https://tepper.cmu.edu/prospective-students/executive-education/leadership-forwomen/leadership-and-negotiation-academy-for-women

Council of Economic Advisors (2015). Gender Pay Gap: Recent Trends and Explanations. Retrieved from https://obamawhitehouse.archives.gov/sites/default/files/docs/equal_pay_issue_brief_fina 1.pdf

Crosby, E. (1993). Review: librarianship: the erosion of a woman's profession by Roma M. Harris. $R Q, 33(1), 147-148$. 
Hansen, D., Gracy, K., \& Irvin, S. (1999). At the pleasure of the board: women librarians and the Los Angeles Public Library, 1880-1905. Libraries \& Culture, 34(4), 311-346.

Hickey, A. (2006). Cataloguing men: charting the male librarian's experience through the perceptions and positions of men in libraries. The Journal of Academic Librarianship 32(3), 286-295. doi:http://dx.doi.org.proxycu.wrlc.org/10.1016/j.acalib.2006.02.009\

Patten, E. (2016, July 01). Racial, gender wage gaps persist in U.S. despite some progress. Retrieved from http://www.pewresearch.org/fact-tank/2016/07/01/racial-gender-wagegaps-persist-in-u-s-despite-some-progress/\#

Rubin, R. E. (2016). Foundations of library and information science (4th ed). New York: ALA Neal-Schuman.

Saujani, R., \& Sweet, J. (2016, December 27). The gender gap in computer science is hurting U.S. businesses. Retrieved from https://www.washingtonpost.com/opinions/the-gendergap-in-computer-science-is-hurting-us-businesses/2016/12/27/fa4f6680-c247-11e6-95780054287507db_story.html?utm_term $=.856026549$ da7

Simon, J. (1994). The construction of femininity in discourses of the woman librarian: 1890s to 1940s. The Australian Library Journal, 43(4), 257-271. Retrieved from http://dx.doi.org/10.1080/00049670.1994.10755696

Why Gender Diversity Matters in BusinessMBA@Simmons. (2017). Retrieved from https://online.simmons.edu/our-programs/mba/gender-diversity/ 